\title{
Evaluation Of Iron Deficiency Anemia Awareness In a Rural Area: Results From a Survey In a Mediterranean Region Rural Area Of Turkey
}

\author{
Kırsal Bir Alandaki Demir Eksikliği Anemisi Farkındalığını \\ Değerlendirme: Türkiye'nin Akdeniz Bölgesi Kırsal Bir Alanındaki \\ Anketten Sonuçlar
}

\author{
Alparslan Merdin ${ }^{1}$ \\ Hematology Clinic and Bone Marrow Transplantation Unit, University of Health Sciences Ankara Dr. Abdurrahman \\ Yurtaslan Oncology Training and Research Hospital, Ankara, Turkey
}

\section{ÖZET}

GíRIŞ ve AMAÇ: Aneminin bir çok etken ajanı vardır. Burada Türkiye'nin Akdeniz Bölgesi kırsal bir alanındaki insanların demir eksikliği farkındalığının ölçülmesi amaçlandı.

YÖNTEM ve GEREÇLER: Ankete 132 insan katıldı. Katılımcıların hiçbirisi sağlık çalışanı değildi. Anket çalışması Aksu'nun kırsal bir alanında yapıldı. Aksu, Antalya İli’nin bir ilçesidir. Antalya İli ise Türkiye'nin Akdeniz Bölgesi’nde bulunmaktadır. Anket çalışmasında 7 soru soruldu.

BULGULAR: $81(\approx 61 \%)$ katılımcı vücudun demir ihtiyacının en çok kırmızı etten alınabileceğini düşünüyordu. $42(\approx 32 \%)$ katılımcı vücudun demir ihtiyacının en çok sebzelerden alınabileceğini düşünüyordu. Ve $9(\approx 7 \%)$ katılımcı vücudun demir ihtiyacının en çok meyvelerden alınabileceğini düşünüyordu. Bunun yanında, $94(\approx 71$ \%) katılımcı demir eksikliğine bağlı kansızlık olabileceğini biliyordu.

TARTIŞMA ve SONUÇ: Demir eksikliği anemisi (DEA) bir halk sağlığı sorunudur. DEA hakkındaki sosyal farkındalığı bilmek, DEA'yı azaltmak için sosyal programlar yapmada yararlı olabilir. Kırsal alanlardaki insanların demirden zengin besinler tüketilmesi konusundaki farkındalığının arttırılması için sağlı organizasyonları düzenlenmelidir.

Anahtar Kelimeler: Demir eksikliği anemisi, farkındalık, Türkiye'nin Akdeniz Bölgesi, kırsal alan

\begin{abstract}
INTRODUCTION: There are many causative agents of anemia. Hereby, it is aimed to evaluate the iron deficiency awareness of the people in a rural area of Turkey's Mediterrenean Region.

MATERIAL and METHODS: 132 people participated in the survey. None of the participants were health workers. The survey was conducted in a rural area of Aksu. Aksu is a district of Antalya Province. And, Antalya Province is in the Turkey's Mediterrenean Region. 7 questions were asked in the survey.

RESULTS: $81(\approx 61 \%)$ participants thought that iron requirement of the body could be obtained mostly from the red meat. $42(\approx 32 \%)$ participants thought that iron requirement of the body could be obtained mostly from the vegetables. And $9(\approx 7 \%)$ participants thought that iron requirement of the body could be obtained mostly from the fruits. Besides, $94(\approx 71 \%)$ participants knew that iron deficiency could cause anemia.

DISCUSSION AND CONCLUSION: Iron deficiency anemia (IDA) is a public health problem. Knowing the social awareness about IDA may help to make social programs for reducing the iron deficiency anemia. Health organisations must be conducted to increase the awareness of people in rural areas about consuming iron rich foods.
\end{abstract}

Keywords: Iron deficiency anemia, awareness, Mediterranean Region of Turkey, rural area 


\section{INTRODUCTION}

Anemia is one of the common findings of outpatient units. There are many causative agents of anemia. Iron deficiency, vitamine B12 deficiency, folic acid deficiency, gastrointestinal bleeding, malignancy, urinary bleeding, impaired gastrointestinal absorption, thalasemia, erthrocyte enzyme defects are some known reasons of anemia. Worldwide prevalence of anaemia was estimated as $24.8 \%$ - A WHO(World Health Organization) scientific group reported a hemoglobine treshold for anemia as $12 \mathrm{mg} / \mathrm{dL}$ in adult nonpregnant females in 1968 (2). It was also reported a hemoglobine treshold for anemia as $13 \mathrm{mg} / \mathrm{dL}$ in adult males (2) . Lastly, the same aforementioned WHO scientific group reported a hemoglobine treshold for anemia as $11 \mathrm{mg} / \mathrm{dL}$ in pregnant adult females (2). Hereby, it is aimed to evaluate the iron deficiency awareness of the people in a rural area of Turkey's Mediterrenean Region.

\section{MATERIAL and METHODS}

132 people participated in the survey. All of the participants were 18 or over 18 years old. None of the participants were health workers. The survey was conducted in a rural area of Aksu. Aksu is a district of Antalya Province. And Antalya Province is a province in southern Turkey. In addition to this, Antalya Province is in the Turkey's Mediterrenean Region. 7 questions were asked in the survey. The survey questions and their answer choices are listed below. All of the participants have chosen only one answer choice for each survey question.

Question 1. Do you know that iron deficiency could cause anemia?
a) Yes
b) No

Question 2. From which foods below could the iron requirement of the body be obtained mostly?
a) Vegetables
b) Red meat
c) Fruits

Question 4. Which of the following could be caused by anemia ? (Choose only one choice)
a) Pallor
b) Weakness
c) Fatigue
d)

Forgetfulness

e) All of them

Question 5. Were you or any of the people around you diagnosed with iron deficieny by a medical doctor previously?
a) Yes
b) No

Question 6. Do you know there are drugs containing iron?
a) Yes
b) No

Question 7. Which of the following do you think could result in a lack of iron in the body? (Choose only one choice)

a) Nutritional deficiency b) Gastrointestinal bleeding c) Menstrual bleeding

d) All of them

\section{RESULTS}

94( $\approx 71 \%)$ participants knew that iron deficiency could cause anemia (Figure 1). 42 $(\approx 32 \%)$ participants thought that iron requirement of the body could be obtained mostly from the vegetables (Figure 2 ). $81(\approx 61$ $\%)$ participants thought that iron requirement of the body could be obtained mostly from the red meat (Figure 2). And 9( $\approx 7 \%)$ participants thought that iron requirement of the body could be obtained mostly from the fruits (Figure 2).126 $(\approx 95 \%)$ participants thought that iron deficiency could be more frequently found in women (Figure 3). On the other side, $6(\approx 5 \%)$ participants thought that iron deficiency could be more frequently found in men (Figure 3).

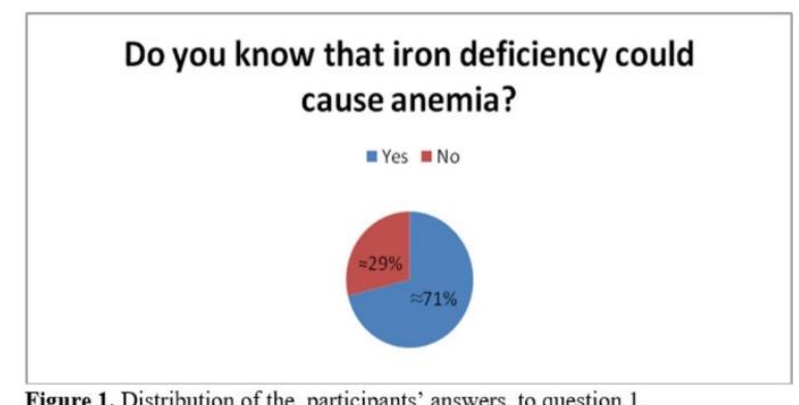

Figure 1. Distribution of the participants' answers to question 1 .

Question 3. In which of the below could iron deficiency be more frequently found?

a) Women b) Men

Adress for correspondence: Alparslan Merdin, Ankara Dr. Abdurrahman Yurtaslan Onkoloji Eğitim ve Araştırma Hastanesi, Hematoloji Kliniği, Demetevler/ Yenimahalle Ankara-

Türkiye

e-mail: alparslanmerdin@yahoo.com

Available at www.actaoncologicaturcica.com

Copyright (Ankara Onkoloji Hastanesi 


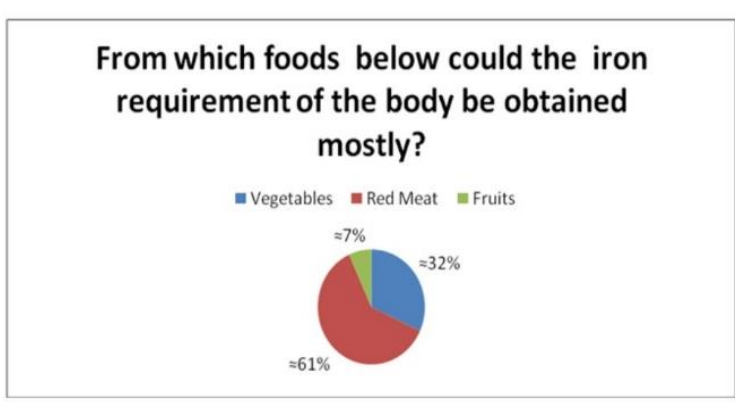

Figure 2. Distribution of the participants' answers to question 2.

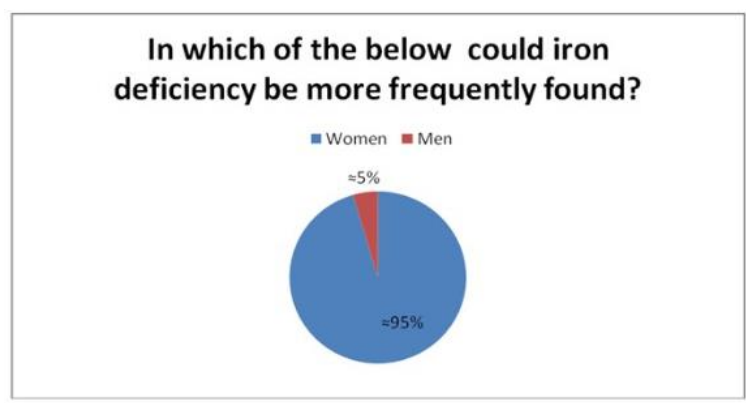

Eigure 3. Distribution of the participants' ansuxers to question 3.

$85(\approx 65 \%)$ of the all participants thought that all of the choices in the fourth question could be caused by anemia (Figure 4). And distribution of the participants' answers to question 4 was shown in figure $4.68(\approx 52 \%)$ of the all participants answered "Yes" to the fifth question (Figure 5). And $64(\approx 48 \%)$ of the all participants answered "No" to the fifth question (Figure 5). $52(\approx 39 \%)$ of the all participants did not know about the drugs containing iron (Figure 6). 45( $\approx 34 \%$ ) participants thought that all of the choices in the seventh question could result in a lack of iron in the body (Figure 7). Lastly, distribution of the participants' answers to question 7 was shown in figure 7 .

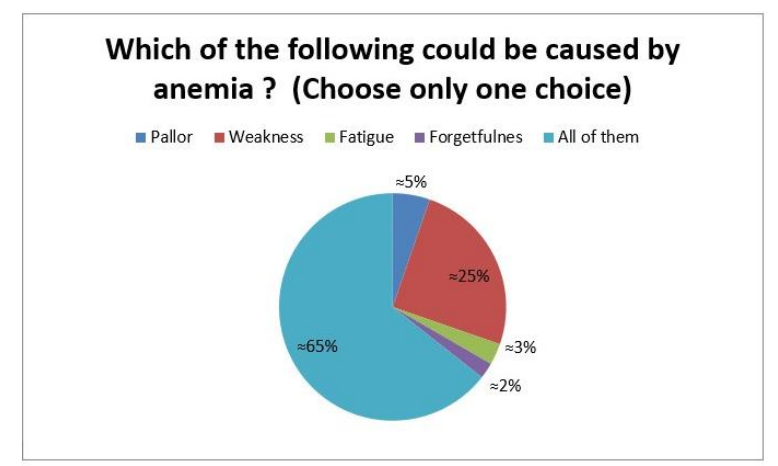

Figure 4. Distribution of the participants' answers to question 4 .

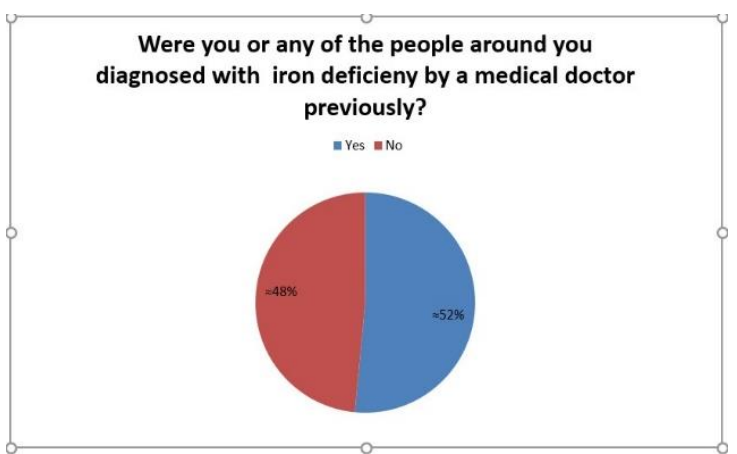

Figure 5. Distribution of the participants' answers to guestion 5 .

Do you know there are drugs containing iron? $=$ Yes $=$ No

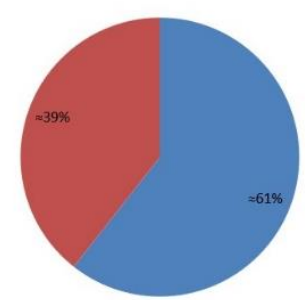

Figure 6. Distribution of the participants' answers to question 6 .

Do you know there are drugs containing iron? $m=$ Yes $=$ No

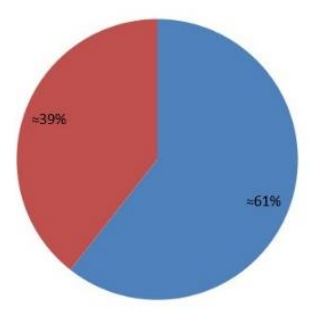

Eigure 6. Distribution of the participants' answers to guestion 6 .

\section{DISCUSSION}

Iron is an element and it is involved in hemoglobine synthesis. Hemoglobine carries oxygen from lungs to tissues. Gastrointestinal bleeding, menstrual bleeding and nutritional deficiency may cause iron deficiency. Malabsorption associated diseases such as coeliac disease and Chron's disease could also result in iron deficiency. On the other side, low iron stores and iron deficiency anemia are not the same things. Low iron stores could result in anemia. But, low iron stores could also be seen when hemoglobine levels are in normal ranges. 
In addition to this, pica could also be seen as an eating disorder in patients with IDA $(3,4,5)$. Hussain $\mathrm{T}$ et al. reported that $77.9 \%$ of the women participants in their study were aware of the term iron deficiency anemia (6). On the other hand, $94(\approx 71 \%)$ participants in this study knew that iron deficiency could cause anemia (Figure 1). However, the participants in the study of Hussain T et al. were all women (6). In a study conducted to determine the nutritional knowledge among adolescent girls, it was found that $30 \%$ girls knew about the sources of iron (7). On the other hand, $81(\approx 61 \%)$ participants in this study thought that iron requirement of the body could be obtained mostly from the red meat (Figure 2). And $\approx 39 \%$ of the all participants in this study thought that iron requirement of the body could be obtained mostly from the vegetables or fruits (Figure 2). Most of the participants in this study were farmers. And these farmers mostly grow vegetables in the greenhouses. They also eat vegetables more than meat. So that their work and eating habit might have an effect on their answers.

\section{CONCLUSION}

Iron deficiency anemia is a public health problem. Knowing the social awareness about IDA may help to make social programs for reducing the iron deficiency anemia. Health organisations must be conducted to increase the awareness of people in rural areas about consuming iron rich foods.

\section{List of Abbreviations}

IDA: Iron deficiency anemia

WHO: World Health Organization

\section{DECLARATIONS}

Ethics approval and consent to participate: The study was approved by the local ethics committee ( Decision number: 2017-11/01). The name of the local ethics committee is "T.C. Sağlık Bakanlığı Sağlık Bilimleri Üniversitesi Dr. Abdurrahman Yurtaslan Onkoloji Sağlık Uygulama ve Araştırma Merkezi Klinik Araştırmalar Etik Kurulu'’. Consent was taken from the participants.

Consent for publication: I give my full permission for the publication of this study.

Competing interests: No conflict of interest was declared by the author.

\section{REFERENCES}

1. McLean E, Cogswell M, Egli I, Wojdyla D, de Benoist B. Worldwide prevalence of anaemia, WHO Vitamin and Mineral Nutrition Information System, 1993-2005. Public Health Nutr. 2009 Apr;12(4):44454.

2. World Health Organization. Nutritional anaemias: Report of a WHO scientific group.WHO Technical Report Series, No. 405. Geneva: WHO,1968.

3. http://whqlibdoc.who.int/trs/WHO_TRS_405.pdf

4. Mensah FO, Twumasi P, Amenawonyo XK, Larbie C, Jnr AK. Pica practice among pregnant women in the Kumasi metropolis of Ghana. Int Health. 2010 Dec;2(4):282-6.

5. Nafil H, Tazi I, Mahmal L. [Prevalence of pica in iron deficiency anemia in Marrakech (Morocco)]. Med Sante Trop. 2015 JulSep;25(3):273-5.

6. Barton JC, Barton JC, Bertoli LF. Pica associated with iron deficiency or depletion: clinical and laboratory correlates in 262 non-pregnant adult outpatients. BMC Blood Disord. 2010 Dec 22;10:9.

7. Hussain T, Shu LY. Awareness of Iron Deficiency Anemia among Women of Reproductive Age in Hubei Province, China. Asian Journal Of Medical Sciences. 2010; 1(1): 12-13.

8. Priyanka Pareek, Asfia Hafiz. A Study on Anemia Related Knowledge Among Adolescent Girls. International Journal of Nutrition and Food Sciences. Vol. 4, No. 3, 2015, pp. 273-276. doi: 10.11648/j.ijnfs.20150403.14 